PRAGATI: Journal of Indian Economy Volume 4, Issue 1, January-June 2017, pp. 109-119 doi:10.17492/pragati.v4i01.9546

\title{
Microfinance as a way of Financial Inclusion: A Study of Cooch Behar District of West Bengal
}

\author{
Bhajan Chandra Barman*
}

\begin{abstract}
As a financial intermediary, banks contribute to the economic growth of the country by identifying the entrepreneurs with the best chances of successfully initiating new commercial activities and allocating credit to them. However, it is disheartening to note that the number of people with access to the products and services offered by the banking system continues to be very limited even after introduction of inclusive banking initiatives in the country through measures such as the cooperative movement, nationalisation of banks, creational of regional banks, etc. Against this backdrop, we can think about microfinance programme which plays an important role towards financial inclusion. People's participation in credit delivery, recovery and linking of formal credit institutions to borrowers through the intermediation of self-help Groups (SHGs) have been recognised as a supplementary mechanism for providing credit support to the rural poor. The basic objective of the study is to analyse the role of SHGs towards financial inclusion of the rural poor in Cooch Behar District of West Bengal. From the discussion it is found that after joining the SHGs, 1,37,978 rural poor have been able to connect with the formal financial institutions in the district of Cooch Behar. Thus the microfinance programme in the form of SHG-Bank linkage model has played an important role towards financial inclusion of the rural poor in this district.
\end{abstract}

Keywords: Microfinance; SHGs; Saving Linkage Groups; Credit Linkage Groups.

\subsection{Introduction}

Financial inclusion efforts are not new; both the government and Reserve Bank have been pursuing this goal over the last several decades through building the rural cooperative structure in the 1950s, the social contract with banks in the 1960s and the expansion of bank branch networks in the 1970s and 1980s.

*Assistant Professor, Department of Economics, Netaji Nagar College, Kolkata, West Bengal, India. (Email id: bhajanbarman@gmail.com) 
These initiatives have paid off in terms of a network of branches across the country. In developing economics like ours, the banks, as mobilisers of savings and allocators of credit for production and investment, have a very critical role. As a financial intermediary, the banks contribute to the economic growth of the country by identifying the entrepreneurs with the best chances of successfully initiating new commercial activities and allocating credit to them. At a minimum, all retail commercial and other payment related products. Thus, inherently, the banking sector possesses a tremendous potential to act as an agent of change and ensure redistribution of wealth.

However, it is disheartening to note that the number of people with access to the products and services offered by the banking system continues to be very limited even years after introduction of inclusive banking initiatives in the country through measures such as the cooperative movement, nationalization of banks, creational of regional banks, etc. the extent of financial exclusion has been staggering According to Amartya Sen " the thrust of development policy in India has undergone a paradigm shift from an exclusive focus on efficiency to one on equity; from the rate and pattern of growth of growth and on inequalities, distribution of income and wealth to the extent to which people are deprived of the requirements for lending a fulfilling life and suffer capability deprivation". Over the past five years, the Reserve Bank of India, as also other policy makers have resolutely pursed the agenda of financial inclusion and achieved discernible progress in improving access to financial services for the masses.

However, the progress is far from satisfactory as evident by the World Bank Findex Survey (2012). According to the survey findings, only 35 per cent of Indian adults had access to a formal bank account and 8 per cent borrowed formally in the last 12 months. Only 2 per cent adults used an account to receive money from a family member living in another area and 4 per cent used an account to receive payment from the government. The proportion of people having any kind of life insurance cover was as low as 10 per cent and proportion having non-life insurance was an abysmally low 0.6 per cent. People having debit cards comprise only 13 per cent and those having credit cards only a marginal 2 per cent. The National Sample Survey data revealed that nearly 51 per cent of farmer households in the country did not seek credit from either institutional or non-institutional sources of any kind.

Against this backdrop, we can think about microfinance programme which plays important role towards financial inclusion. Experience of different anti-poverty and other social welfare programmes within the country and elsewhere have shown that the key to its success lie in the participation of community based organizations at the grass root level. People's participation in credit delivery, recovery and linking of formal credit institutions to borrowers through the intermediation of self-help Groups (SHGs) have 
been recognised as a supplementary mechanism for providing credit support to the rural poor. Microfinance is recognized as a cost effective and sustainable way of taking the banking system to the rural poor. The broad principle behind microfinance initiatives is; (i) to act as a cost effective hassle-free avenue for the formal financial sector to expand its coverage of poor; (ii) to develop effective collateral substitutes; (iii) to emphasize on the poor masses; and (iv) to focus on the objectives of macroeconomic growth.

The paper is divided into six sections as follows: Section 1 deals with introduction; section 2 deals with review of literature; section 3 outlines the objectives and methodology; section 4 analyses the objective of financial inclusion; section 5 provides a brief scenario of microfinance of Cooch Behar district; and section 6 provides conclusions and suggestions.

\subsection{Review of Literature}

This section reviews some existing literature on the subject. Sangwan (2008) empirically ascertained the determinants of financial inclusion and studied the relevance of Self Help Groups (SHGs) in achieving financial inclusion. He found that the financial inclusion of adults above 19 years of age was 63 per cent in terms of saving accounts and 16 per cent in terms of credit accounts and about 37 per cent adults in India did not use financial services. The study revealed that the branch density had positive and significant coefficient with the percentage of adults having saving as well as credit accounts. Literacy percentage had surprisingly negative relationship with both percentage of saving as well as credit accounts of adults. It may be partly because of lack of financial education among the educated ones. The results showed that the persons having low income and less geographical access to bank (e.g., agricultural labourers, marginal and small farmers, migrant labourers, tribal and women) were excluded from the financial inclusion. It suggested that SHGs could play significant role in achieving the financial inclusion especially for women and low-income families.

Ghorude (2009) concluded that the commercial banks must provide a greater linkage to SHGs in providing them higher amount of bank loan. More innovation in the form of business facilitators and correspondents is needed for banks to increase their outreach for banks to ensure financial inclusion. Maheswari (2009) concluded that micro finance has changed many lives in diverse societal setting across the globe. It tries to create a more inclusive financial universe for the whole society. By trying to bring more people in this network, an inclusive financial sector allows poor and low-income people to access credit, insurance, remittance and savings products. 
Gupta (2012) observed that with increasing demand for rural finance, and the inadequacies of formal sources of finance, the Microfinance Institutions have immense opportunities in the new incarnation of microcredit in India. Non-governmental organisations have played a commendable role in promoting Self Help Groups by linking them with banks. There is, therefore, a need to evolve an incentive based package which should motivate these NGOs to diversify themselves into other backward areas.

Shankar (2013) in his study examined that MFIs do break down many barriers to financial inclusion MFI penetration in the country is skewed and excludes some areas neglected by the banking sector, suggesting a need for policy incentives to encourage expansion to those areas.

From the above review of literature, two points can be justified behind selecting microfinance and poverty for the present study. Firstly, although there are so many studies on microfinance and financial inclusion, it is clear that existing literature is silent about the status of the financial inclusion initiatives from the outreach. Secondly, no study has been made so far to assess the impact of microfinance on financial inclusion in Cooch Behar district of West Bengal. The present paper aims to fulfill this research gap in literature.

\subsection{Objectives and Methodology}

The main objectives of the study are as follows:

(i) To examine the impact of SHGs on financial inclusion of the rural poor in Cooch Behar district of West Bengal;

(ii) To find out whether SHGs have been able to reach the financial services to the rural poor women in Cooch Behar District or not;

(iii) To know how many poor people of Cooch Behar District were utilising financial inclusion services through SHGs.

For our study purpose we have mainly used secondary data related to Swarnajayanti Gram Swarojgar Yojana (SGSY) collected from District Rural Development Cell of Cooch Behar district (DRDC), Panchayat and Rural Development Department (P\&RDD), Government of West Bengal. Moreover, we have also collected data from various journals, books and available website during 1999-2014. In this study, the impact of microfinance on financial inclusion has been shown through SHG-Bank linkage model. Through this model the performance of different banks in Cooch Behar district regarding saving and credit linkage self-help groups (SHGs) under SGSY has been shown. We have used percentage to analyse the data. 


\subsection{Objectives of Financial Inclusion}

Financial inclusion can be defined as the "process of ensuring access to appropriate financial products and services needed by all sectors of the society in general and vulnerable groups such as weaker sections and low income groups in particular, at an affordable cost in a fair and transparent manner by regulated, mainstream institutional players" (Chakraborty, 2013). Financial inclusion and financial literacy can be considered as twin pillars where financial inclusion acts on the supply side i.e., for creating access and financial literacy acts from the demand side i.e., creation a demand for the financial products and services. Financial inclusion not only means that opening of saving bank account but signifies creation of awareness about the financial products such as credit, insurance etc.

In fact, the main reason for financial exclusion is poverty. Most of the people of Cooch Behar district are below poverty line. Their income is so low that they cannot think about their saving. Not only that, the other reasons why they are excluded from the formal financial institution are lack of awareness, illiteracy, distance from branch, branch timings, cumbersome documentation and procedures, unsuitable products, language, staff attitudes, etc. That is why the poor of the rural areas are bound to take money from informal credit sources, such as mahajan, money lenders, friends, relatives and so on.

In India more than half of the poor are financially excluded from the country's formal banking sector. Thus, it is important to understand that the purpose of financial inclusion in India is the integration of the financially excluded into the mainstream banking system, thus providing them a platform for empowerment out of their state of economic and financial deprivation. In India, financial inclusion is being carried out under the Reserve Bank of India through the "Lead Bank." A lead bank is identified for every state and is mandated to cover all villages, with a population of 2000 or more, with a bank branch within $5 \mathrm{~km}$., within the stipulated time period.

Let us now turn to how financial inclusion can help the society and the economy. Financial inclusion has the ability to generate positive externalities. It leads to increase in savings, investment and thereby, spurs the processes of economic growth. It also provides a platform for inculcation the habit of saving money, especially among the poor who have been living at the bottom of the pyramid, mainly because of absence of savings which make them a vulnerable lot. Presence of banking services and products aim to provide a critical tool to inculcate the savings habit. It also creates avenues of formal credit to the unbanked population who are otherwise dependent on informal sources of credit like family, friend, and moneylenders. It will open the doors of formal 
remittance facilities to the low income and unbanked populace who, presently, are forced to use all kinds of informal and costly ways of sending money from one place to another. As we all know, financial inclusion has now been viewed as a remedy to plug gaps leags in distribution of government benefits and subsidies through direct benefit transfers to beneficiaries' bank accounts rather than through subsidizing products and making cash payments. Thus, on the whole, financial inclusion has the potential to bring the unbanked masses into the formal banking system, channelise their savings, stoke their entrepreneurial ambitions by making available credit and thus give a fillip to the economy.

\subsection{Microfinance Scenario in Cooch Behar District}

Cooch Behar district is one of the backward districts in West Bengal. According to 2011 census, there are 665720 households in Cooch Behar district of which 596,027 households are in rural areas. This district occupies $17^{\text {th }}$ position in terms of population in West Bengal. Cultivators and agricultural labourers constitute the main workforce of the district. There are 32.3 per cent cultivators and 34.7 per cent agricultural labourers of the total workers in the district.

In Cooch Behar district, there are three major streams under which SHGs are promoted. These are: i) NABARD's SHG Bank linkage programme (SBLP); ii) SHGs under SGSY (P\&RDD); and iii) NGOs promoting SHGs. Among them SHGs under SGSY is the main pillar in this regard. SGSY was launched in Cooch Behar district in April, 1999 and formation of SHGs really started from 2000-2001. SGSY is a holistic self-employment scheme aimed at sustainable income to rural poor especially the women belonging to the BPL households through income generating activities so as to bring them out of the poverty line. There is considerable number of poor families who have not yet been associated with SHGs. Summary position of SHGs under SGSY of Cooch Behar district as well as West Bengal up to October 2013 is given below.

From Table 1, it can be seen that total 4.67 lakh SHGs have been formed in West Bengal during 1999 to 2013 whereas in Cooch Behar district this figure was 23756 i.e. 5.08 per cent of the state total. In this district, grade-I and grade-II passed groups and exclusively women SHGs were 5.88 per cent, 4.09 per cent and 5.84 per cent respectively of the state total during the same period. We found that Cooch Behar district occupies $7^{\text {th }}$ position in the state regarding the group formation.

The year-wise formation and cumulative position of SHGs under SGSY are given in Table 2. From the Table, it is observed that formation of SHGs is not uniformly spread out over the years. During 1999-2000, only 320 groups have been formed. Then 
the rate of group formation increase over the years. During the year 2013-14, highest number of groups has been formed.

Table1: SHGs under SGSY in Cooch Behar district as well as West Bengal as on October 2013

\begin{tabular}{|l|c|c|c|}
\hline Particular & West Bengal & Cooch Behar & $\begin{array}{c}\text { \% against } \\
\text { State }\end{array}$ \\
\hline No. of SHGs formed (since 1.4.1999) & 467000 & 23756 & 5.08 \\
\hline No. of women groups (since 1.4.1999) & 362905 & 21215 & 5.84 \\
\hline $\begin{array}{l}\text { No. of Grade-I Passed SHGs (since } \\
\text { 1.4.1999) }\end{array}$ & 363197 & 21361 & 5.88 \\
\hline $\begin{array}{l}\text { No. of Grade-II Passed SHGs (since } \\
\text { 1.4.1999) }\end{array}$ & 161372 & 6602 & 4.09 \\
\hline
\end{tabular}

Source: Panchayat \& Rural Development Department, Cooch Behar, 2013-14

Table 2: Year wise Formation of SHGs in Cooch Behar District during 1999-2000 to 2013-14

\begin{tabular}{|c|c|c|}
\hline Year & No. of SHGs & No. of SHGs Cumulative \\
\hline $1999-2000$ & 320 & 320 \\
\hline $2000-2001$ & 707 & 1027 \\
\hline $2001-2002$ & 1094 & 2121 \\
\hline $2002-2003$ & 1481 & 3602 \\
\hline $2003-2004$ & 1868 & 5470 \\
\hline $2004-2005$ & 2255 & 7725 \\
\hline $2005-2006$ & 1409 & 9134 \\
\hline $2006-2007$ & 1233 & 10367 \\
\hline $2007-2008$ & 1419 & 11786 \\
\hline $2008-2009$ & 758 & 12544 \\
\hline $2009-2010$ & 2173 & 14717 \\
\hline $2010-2011$ & 2510 & 17227 \\
\hline $2011-2012$ & 1777 & 19004 \\
\hline $2012-2013$ & 2186 & 21190 \\
\hline $2013-2014$ & 2566 & 23756 \\
\hline Total & $\mathbf{2 3 7 5 6}$ & - \\
\hline
\end{tabular}

Source: Panchayat \&Rural Development Department, Cooch Behar, 2013-14 
The year wise formation of SHGs has been shown in Figure 1. From the Figure, it is found that in the initial stage, the formation of SHGs was very low only 320 groups. After that the growth rate of formation of group increases frequently till 2004-05. After 2004-05, growth rate decreases and it continue to be till 2009-10. Again, from the year 2010-11, growth rate increases.

\section{Figure 1: Year wise formation of SHGs in Cooch Behar district}

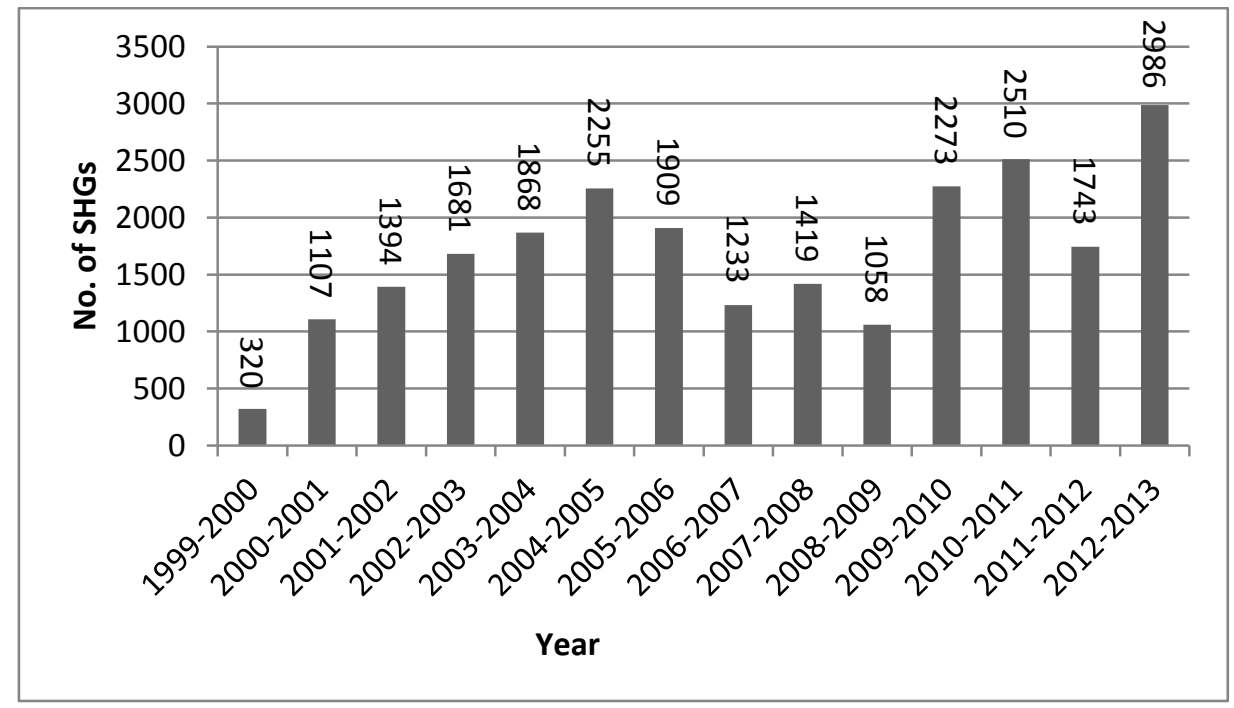

Source: Panchayat \&Rural Development Department, Cooch Behar, 2013-14

The unique aspect of microfinance in India is that it is delivered through a variety of channels. These include branches of commercial banks and Regional Rural Banks (RRBs) directly dispensing microcredit and through SHGs linked to bank branches. The Regional Rural Banks and other banks have benefited a large number of families living below the poverty line as identified under the scheme of SGSY. Table 3 shows the performance of different banks regarding saving and credit linkage groups during the period 1999-2013. From Table 3, it can be seen that under the SGSY programme, over 1.37 lakh rural households have been able to access to regular savings through 23.75 thousand SHGs linked to banks. About 89.92 per cent of these SHGs are credit linked through the SGSY programme. Further, it can be observed that only three banks, one regional rural bank and other two commercial banks, play important role in financial inclusion of the SHG members. These three banks are Uttar Banga Kshetriya Gramin Bank UBKGB), CBI and SBI. 
Table 3: Performance of Banks Regarding Saving and Credit Linkage Groups

\begin{tabular}{|l|c|c|c|}
\hline \multicolumn{1}{|c|}{ Bank } & No. of SLGs & No. of CLGs & No. of Members \\
\hline Allahabad Bank & 787 & 707 & 4322 \\
& $(3.31)$ & $(3.31)$ & $(3.13)$ \\
\hline Bank of India & 147 & 94 & 834 \\
& $(0.62)$ & $(0.44)$ & $(0.60)$ \\
\hline Bank of Baroda & 681 & 641 & 2948 \\
& $(2.87)$ & $(3.0)$ & $(2.14)$ \\
\hline CBI & 8596 & 7726 & 40652 \\
& $(36.18)$ & $(36.17)$ & $(29.46)$ \\
\hline SBI & 3131 & 2909 & 23078 \\
& $(13.18)$ & $(13.62)$ & $(16.73)$ \\
\hline UBI & 1060 & 911 & 5694 \\
& $(4.46)$ & $(4.26)$ & $(4.13)$ \\
\hline UCO Bank & 140 & 137 & $(1409$ \\
& $(0.59)$ & $(0.64)$ & 59041 \\
\hline UBK Gramin Bank & 9214 & 8236 & $(42.79)$ \\
\hline Total & $(38.79)$ & $(38.56)$ & $\mathbf{1 3 7 9 7 8}$ \\
& $\mathbf{2 3 7 5 6}$ & $\mathbf{2 1 3 6 1}$ & $(\mathbf{1 0 0})$ \\
\hline
\end{tabular}

Source: District Rural Development Cell, Cooch Behar, 2013-14

Note: $S L G s=>$ Saving Linkage Groups;CLGs=> Credit Linkage Groups

Figure 2: Bank-wise Saving and Credit Linkage Groups

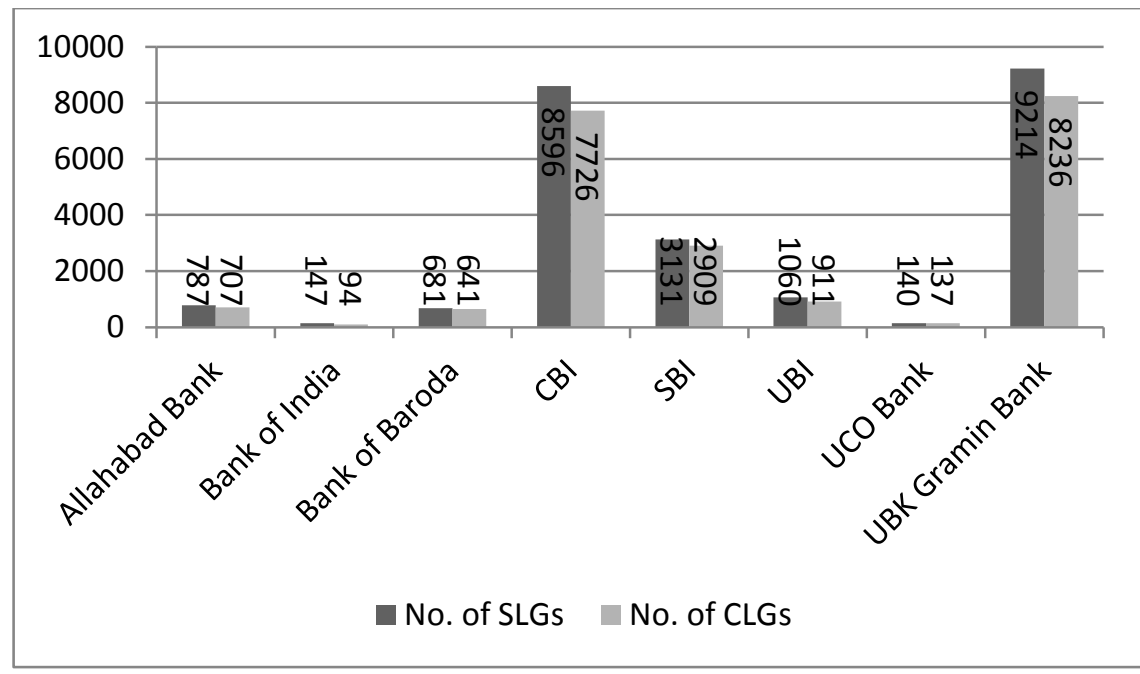

Source: District Rural Development Cell, Cooch Behar, 2013-14 
Among 23756 saving linkage groups, UBKGB, CBI and SBI lead to 9214 groups (38.79 per cent), 8596 groups ( 36.18 per cent) and 3131 (13.18 per cent) respectively. Again, so far as credit linkage groups are concerned, among 21361 groups, UBKGB, CBI and SBI lead to 8236 groups (38.56 per cent), 7726 groups (36.17 per cent) and 2909 groups (13.62 per cent) respectively. UCO Bank and Bank of India show low performance for financial inclusion of the SHG members.

The bank-wise saving as well as credit linkage groups have been shown in the Figure 2. It can be seen in Figure 2 that Uttar Banga Kshetriya Gramin Bank mobilises highest number of saving as well as credit linkage groups followed by CBI and SBI. Other banks such as Allahabad Bank, Bank of India, Bank of Baroda and UCO Bank lead lower number of SHGs.

\subsection{Conclusions and Suggestions}

\subsection{Conclusion}

From the above discussion, it was found that total 23756 groups and 137978 members have been linked with the saving banks deposit account in Cooch Behar District from $1^{\text {st }}$ April 1999 to October 2013; total 21361 groups have been linked with credit by different banks during 1999-2013 and total 6602 groups have been provided with small entrepreneurial credit as at the end of October 2013. In this way, microfinance programme in the form of SHG-Bank linkage model has been able to bring thousands of rural poor of Cooch Behar district in the network of banking system. Thus, it can be concluded that microfinance programme plays an important role in financial inclusion of the rural poor across the country.

\subsection{Suggestions}

The following suggestions may prove to be useful for universal financial inclusion. First, if microfinance programme works actively in the rural areas then more financial inclusion will happen and acceleration of financial inclusion will increase. As a result, the poor of the rural areas will be saved from the village moneylenders who charge high rate of interest. Second, the access to finance for the poor should be made available through intermediaries, SHGs and MFIs and such others. Third, in order to achieve the goal of financial inclusion, policymakers, banks, MFIs, NGOs and regulators have to work together. Fourth, banks should provide some relaxations to the poor in terms and conditions for having access to formal credit. Fifth, microfinance programme can help to increase the speed of financial inclusion through financial education 
programs. With the help of basic literacy programme, financial stability can be achieved and thus universal financial inclusion is possible.

\section{References}

Gupta, Avnesh Kumar. (2012). Microfinance and strategy of financial inclusion in India. Journal of Economics and Sustainable Development, 3(10), 100-105.

Chattopadhyay, S.K. (2011). Financial inclusion in India: A case study of West Bengal. WPS (Deptt.), RBI Working Paper Series WPS (DEPR): 8/2011, Department of Economic and Policy Research, RBI.

Chakraborty K.C. (2012). The first mile walk into financial inclusion- Thinking differently. RBI Monthly Bulletin, September.

District Rural Development Cell (DRDA). (2013). Cooch Behar Zilla Parishad, SGSY Annual Physical and Financial Progress Report up to October, 2013, Panchayat and Rural Development Department, Govt. of West Bengal.

Ghorude, K.N. (2009). Microfinance for financial, industrial, sustainable rural development. Southern Economist, 46(8), 1147-50.

Maheswari, T. (2009). Microfinance: An agent for financial inclusion. Indian Economic Panorama, 19(3A), 56-57.

Shankar, S. (2013). Financial inclusion in India: Do microfinance institutions address access barriers? Journal of Entrepreneurship Perspectives, 2(1), 60-74.

Sangwan, S. S. (2008). Financial inclusion and self-help groups. Retrieved from http://www. nabard.org/databank/IARD\%20Web/csidfiles/Financial\%201nclusion\%20 and $\% 20 \mathrm{SHGs}$ 